\title{
PENINGKATAN AKTIVITAS DAN PRESTASI BELAJAR MATEMATIKA MELALUI METODE MODELLING THE WAY PADA SISWA KELAS IX SMP
}

\author{
INDRA KURNIAWAN \\ Universitas Indraprasta PGRI, J1 Nangka No 58 C Jagakarsa, Jakarta Selatan; \\ Inkur.master@gmail.com
}

\begin{abstract}
Abstrak. Penelitian ini bertujuan meningkatkan aktivitas dan prestasi belajar matematika dengan penerapan metode Modelling The Way pada siswa kelas IXF SMP tahun ajaran 2012/2013. Penelitian ini merupakan Penelitian Tindakan Kelas (PTK) yang dilaksanakan dalam dua siklus. Setiap siklus terdiri dari tahap persiapan, pelaksanaan tindakan, observasi, dan refleksi. Siklus I dan siklus II dilaksanakan tiga kali pertemuan. Subyek penelitian adalah peserta didik kelas IXF SMP N 1 Ceper yang berjumlah 24 siswa terdiri dari 9 siswa putra dan 15 siswa putri. Data peningkatan aktivitas ini diambil dengan observasi aktivitas siswa selama proses pembelajaran. Sedangkan untuk prestasi belajar diambil dengan menggunakan tes evaluasi yang berbentuk tes uraian. Hasil penelitian menunjukkan bahwa: (1) Aktivitas siswa mengalami peningkatan dari siklus I ke siklus II. (2) Hasil belajar siswa meningkat ditunjukkan dengan adanya peningkatan hasil tes akhir siklus. Rata-rata tes akhir siklus I ke siklus II mengalami peningkatan yaitu dari 71,04 menjadi 79,17. Sedangkan persentase ketuntasan meningkat dari 70,83\% menjadi 87,5\%. Hasil tes akhir siklus II sudah mencapai indikator keberhasilan yang telah ditetapkan, apabila dikelas tersebut terdapat $80 \%$ siswa yang mencapai Kriteria Ketuntasan Minimum (KKM) yaitu 68. Dari hasil penelitian di atas dapat disimpulkan bahwa dengan penerapan metode Modelling The Way dapat meningkatkan aktivitas dan prestasi belajar matematika siswa kelas IX SMP tahun ajaran 2012/2013.
\end{abstract}

Kata kunci: metode Modelling The Way, aktivitas, dan prestasi.

\begin{abstract}
The purpose of this study is to improve SMP students' activity and learning achievement, in mathematics, with the application of the Modeling the Way method, during the 2012/2013 academic year. This research is a classroom action research (PTK) that is conducted in two cycles. Each cycle consists of preparation, action, observation, and reflection. Cycle I and Cycle II are executed within three meetings each. Subjects are IXF grade students of SMP N 1 Ceper amounting to 24 students consisting of 9 male and 15 female students. The data was taken by increased observation of students' activities during the learning process, while their achievement was measured by evaluating them in the form of tests. The results showed that: (1) The students' activities have increased from the first cycle to the second cycle. (2) The students' learning outcomes have also risen, as shown by an increase in the cycle's final test results. The average final test scores, from cycle I to cycle II, has risen from $71.04 \%$ into $79.17 \%$. While the minimum percentage of completeness increased from $70.83 \%$ to $87.5 \%$. The test results of the second cycle have reached the indicator of the success that has been established when $80 \%$ of students reached the Value Minimum Criteria for completeness (KKM), which is 68. From the results above, it can be concluded that the application of the Modelling The Way method can increase the activity and learning achievement of IX SMP students during the 2012/2013 academic year.
\end{abstract}

Keywords: Modeling the Way method, activity, and achievement 


\section{PENDAHULUAN}

Pendidikan sebagai salah satu kebutuhan yang penting dalam kehidupan manusia. Melalui pendidikan, manusia dapat mengembangkan diri maupun memberdayakan potensi alam dan lingkungan untuk kepentingan hidupnya. Selain itu, pendidikan merupakan sarana dan wadah pembinaan sumber daya manusia (SDM). Pendidikan dikatakan unggul apabila dalam prosesnya mampu menciptakan sumber daya manusia yang berkualitas. Untuk meningkatkan kualitas sumber daya manusia diperlukan suatu usaha. Salah satu bentuk usaha tersebut adalah melalui peningkatan mutu pendidikan. Peningkatan mutu pendidikan tidak terlepas dari kualitas proses pembelajaran. Melalui proses pembelajaran akan diperoleh hasil belajar siswa seperti yang diharapkan dalam tujuan pembelajaran yang telah dirumuskan sebelumnya.

Matematika merupakan salah satu bidang studi yang menduduki peranan penting dalam dunia pendidikan karena dengan belajar matematika bisa mengajari kepada siswa untuk menyelesaikan permalahan dalam kehidupan sehari-hari. Hal ini sesuai dalam penelitian Turgut dan Yilmaz (2012) yang menyatakan bahwa mepelajari matematika berguna untuk mengembangkan kemampuan murid yaitu biasanya memahami dan selesaikan masalah dunia nyata. Akan tetapi banyak orang memandang matematika sebagai ilmu kering, abstrak, teoretis, penuh lambang-lambang dan rumus-rumus yang rumit, dan membingungkan. Mereka mungkin pernah mengalami pengalaman yang kurang menyenangkan ketika belajar matematika di sekolah, seperti teknik pembelajaran yang monoton, kurangnya inovasi metode, kurangnya konsep pengembangan diri pada siswa, guru mendominasi pelajaran, kurangnya pemahaman konsep matematika dan aplikasinya dalam kehidupan nyata. Hal tersebut mengakibatkan siswa menganggap bahwa matematika merupakan pelajaran yang sulit dan menakutkan sehingga berakibat aktitas dan prestasi belajar matematika siswa masih rendah.

Berdasarkan hasil observasi peneliti selama kegiatan PPL dan wawancara dengan beberapa siswa kelas IX-F SMPN 3 Ceper antara lain: (1) sebagian siswa tidak menyukai pelajaran matematika, mereka menganggap matematika adalah pelajaran yang sulit dipahami, (2) rendahnya aktivitas siswa dalam pembelajaran matematika yang ditandai antara lain: aktivitas dalam bertanya, mengemukakan pendapat, menjawab pertanyaan, mengerjakan soal di depan kelas, dan mengerjakan soal-soal latihan yang diberikan oleh guru dan (3) Pada saat menerima pelajaran para siswa kurang konsentrasi, sebagian siswa gaduh dan sebagian siswa juga malas untuk mencatat materi yang diberikan guru sehingga mereka kesulitan untuk menyelesaikannya karena catatan yang mereka pelajari kurang lengkap dan materi yang tidak tercatat itu cepat dilupakan. Selain itu, berdasarkan hasil wawancara guru bidang studi matematika mengatakan bahwa hasil belajar matematika siswa yang memenuhi nilai di atas Kriteria Ketuntasan Minimal (KKM) yaitu 68,00 sebanyak 15 siswa $(62,5 \%)$ dan 8 siswa $(37,5 \%)$ lainnya masih di bawah KKM. Hal ini menunjukkan aktivitas dan prestasi belajar matematika masih rendah.

Berdasarkan pengamatan penulis di SMPN 3 Ceper, pembelajaran matematika sudah menggunakan Kurikulum Tingkat Satuan Pendidikan (KTSP). Namun pembelajaran yang dilakukan di kelas IX menggunakan pembelajaran konvensional, pada umumnya lebih didominasi oleh guru atau bersifat "teacher center". Guru menerangkan konsep di depan kelas kemudian diberikan dalam contoh soal dan latihan-latihan. Siswa cenderung pasif dan kurang berpartisipasi dalam pembelajaran. Hal ini terlihat dari aktivitas siswa yang hanya mencatat, mendengar dan sedikit bertanya. Interaksi antara siswa yang satu dengan siswa yang lainnya dalam pembelajaran sangat rendah. Sehingga menimbulkan belajar menjadi monoton dan siswa kurang terlibat secara aktif, akibatnya siswa cepat bosan, kurang serius sehingga materi dirasakan sulit 
Untuk mengatasi masalah tersebut agar tidak berkelanjutan, seorang guru harus dapat memilih metode pembelajaran yang bertujuan untuk lebih memberi kesempatan murid untuk lebih aktif agar siswa lebih kreatif dan dapat mengaplikasaikan kedalam kehidupan seharihari. Hal ini sesuai dalam penelitian Arsaythamby dan Zubainur (2014) yang menyatakan bahwa cara terbaik memperlajari matematika adalah memberi kesempatan kepada siswa untuk lebih aktif sehingga dapat mengaplikasikan dalam konteks keseharian. Penerapan metode yang digunakan secara tepat oleh guru diharapkan siswa dapat belajar secara aktif, keterlibatan siswa secara langsung dalam proses belajar, baik dalam hal mendengar maupun menanggapi pelajaran matematika. Hal ini sesuai dalam penelitian Sutama dan Narimo (2013) yang menyatakan bahwa guru harus mampu memilih metode pembelajaran yang efektif dan menarik sehingga dalam tercapai tujuan pembelajaran. Peneliti mencoba menerapkan metode yang dapat digunakan sebagai salah satu alternatif untuk meningkatkan aktivitas siswa dalam belajar matematika. Aktifitas yang dimaksud adalah aktifitas dalam mengemukakan pendapat baik secara lisan ataupun tertulis, hal ini sesuai dalam penelitian Susanto dan Murnawingsih (2015) yang menyatakan bahwa Aktifitas dalam belajar matematika meliputi ungkapan dari berbagai kesempatan untuk mengkomunkiaskan gagasan yang berupa tulisan ataupun ungkapan lisan. Dengan adaya peningkatan aktivitas siswa diharapkan dapat meningkatkan prestasi belajar matematika. Salah satu metode yang dapat digunakan adalah metode Modelling The Way. Menurut Silberman (1996) Modelling The Way merupakan teknik yang memberikan kesempatan kepada peserta didik untuk berlatih, melalui demonstrasi, keterampilan khusus yang diajarkan di kelas. Peserta didik diberi waktu yang singkat untuk membuat skenarionya sendiri dan menentukan bagaimana mereka ingin menggambarkan kecakapan dan teknik yang baru saja dilakukan di kelas. Dengan demikian metode Modelling The Way itu sesuai untuk diterapkan dalam mengatasi permasalahan pembelajaran matematika. Keterlibatan kecapakan siswa akan meningkatkan aktivitas belajar dan sausana yang menyenagkan pada akhirnya akan meningkatkan prestasi belajar matematika siswa. Hal ini sesuai dalam penelitian Masoan et al (2013) yang menyatakan bahwa menyediakan satu lingkungan belajar menarik, keikut sertaannya murid dengan aktif ke aktivitas selama proses belajar matematik murid akan menjadi lebih paham. Dari uraian di atas menunjukkan adanya keterkaitan antara aktivitas dan prestasi belajar belajar matematika melalui metode Modelling The Way.

Berdasarkan uraian yang telah disampaikan, penelitian ini bertujuan untuk mengetahui ada tidaknya peningkatan aktivitas dan prestasi belajar dengan menggunakan metode pembelajaran Modelling The Way siswa kelas IX SMP Tahun Pelajaran 2012/2013.

\section{METODE}

Penelitian ini dilaksanakan di SMPN 1 Ceper kelas IXF semester gasal tahun ajaran 2012/2013 dengan subjek 24 siswa, terdiri dari 9 siswa putra dan 15 siswa putri. Bentuk penelitian ini adalah penelitian tindakan kelas (PTK) yang terdiri dari dua siklus. Siklus I dan II masing-masing diadakan tiga kali pertemuan. Hal ini sesuai pendapat Arikunto dkk (2008) mengemukakan bahwa PTK adalah sebuah penelitian yang dilakukan di kelas. Dalam penelitian tindakan kelas ini, digunakan metode pembelajaran Modelling The Way. Prosedur penelitian ini meliputi perencanaan, pelaksanaan tindakan, observasi, evaluasi, dan refleksi untuk setiap siklus. Pada akhir setiap siklus diadakan evaluasi untuk mengetahui seberapa besar peningkatan prestasi belajar siswa. Pada setiap siklus akan dilaksanakan pembelajaran dengan metode Modelling The Way.

Teknik pengumpulan data yang digunakan dalam penelitian adalah dengan : (1) Tes yang dilaksanakan pada setiap akhir siklus untuk mengetahui akhir evaluasi pada setiap siklus; (2) observasi adalah kegiatan pengamatan (pengambilan data) untuk mengetahui sejauh mana perkembangan aktifitas siswa. Teknik analisis data dalam penelitian ini 
dilakukan dengan cara: (1) Reduksi Data untuk memisahkan hal-hal yang penting dan tidak penting dari data-data yang terkumpul, (2) Penyajian Data yaitu menyajikan data dalam bentuk tabel yang berisi tentang : rata-rata dan presentasi, (3) kesimpulan.

Untuk mengetahui apakah penerapan metode Modelling The Way dapat meningkatan prestasi belajar matematika, maka diberikan target ketuntasan belajar atau indikator keberhasilan dalam penelitian ini adalah apabila dikelas tersebut $\geq 80 \%$ siswa yang mencapai Kriteria Ketuntasan Minimum (KKM) yaitu 68. selain itu juga meningkatnya peran siswa dalam proses pembelajaran yang dilihat dari peningkatan aktvitas belajar siswa.

\section{HASIL DAN PEMBAHASAN}

Penelitian tindakan kelas dilaksanakan sebagai penerapan pelaksanaan metode Modelling The Way dalam upaya peningkatan aktivitas dan prestasi belajar matematika siswa kelas IX SMP yang dilaksanakan Penelitian dilaksanakan mulai tanggal 12 November 2012 sampai dengan 3 Desember 2012. Sebelum memulai siklus, peneliti melakukan pretest terlebih dahulu, pada tanggal 12 November 2012 peneliti mengadakan pretest. Pretest dilaksanakan selama 40 menit. Hasil pretest disajikan pada Tabel 1.

Tabel 1. Hasil Pretest

\begin{tabular}{|c|c|c|}
\hline No. & Keterangan & Pretest \\
\hline 1 & Nilai Tertinggi & 80 \\
\hline 2 & Nilai Terendah & 20 \\
\hline 3 & KKM & 68 \\
\hline 4 & Rata-rata Kelas & 55,42 \\
\hline 5 & $\%$ Ketuntasan & $41,67 \%$ \\
\hline 6 & $\%$ Ketidaktuntasan & $58,33 \%$ \\
\hline
\end{tabular}

Dari tabel di atas terlihat bahwa persentase ketuntasan klasikal hanya $41,67 \%$, masih banyak nilai siswa yang belum memenuhi KKM, ini berarti prestasi belajar matematika siswa masih rendah. Setelah itu baru dilakukan penelitian dalam siklus. Siklus I terdiri dari 3 kali pertemuan, untuk Kompetensi Dasar yaitu menentukan ruang sampel suatu percobaan dan menghitung peluang masing-masing titik sampel pada ruang sampel suatu percobaan. Siklus II terdiri dari 3 kali pertemuan, untuk Kompetensi Dasar yaitu Menentukan peluang suatu kejadian sederhana. Berdasarkan analisis data pada Siklus I dan Siklus II sebagai penerapan pelaksanaan metode Modelling The Way dalam upaya peningkatan aktivitas belajar matematika siswa dapat disajikan dalam Tabel 2.

Tabel 2. Rekapitulasi Hasil Observasi Aktifitas Siswa Siklus I Dan Siklus II

\begin{tabular}{llccl}
\hline \multirow{2}{*}{ No } & \multicolumn{1}{c}{ Jenis Aktivitas Siswa } & \multicolumn{2}{c}{ Hasil Rata-rata } & \multirow{2}{*}{ Keterangan } \\
\cline { 3 - 4 } & & Siklus I & Siklus II & \\
1 & Memperhatikan Penjelasan & 77,08 & 91,67 & Meningkat \\
& Guru & & & \\
2 & Mencatat & 70,83 & 87,5 & Meningkat \\
3 & Berdiskusi Dalam Kelompok & 58,33 & 77,08 & Meningkat \\
4 & Bertanya & 33,33 & 47,92 & Meningkat \\
5 & Menjawab Pertanyaan & 31,25 & 47,92 & Meningkat \\
6 & Aktif Dalam Kelompok & 75 & 87,5 & Meningkat \\
7 & Berpendapat Dalam Diskusi & 35,42 & 43,75 & Meningkat \\
& Kelas & & & \\
\hline
\end{tabular}




\begin{tabular}{clccc}
\hline 8 & Mengerjakan Soal & 77,08 & 93,75 & Meningkat \\
9 & Tidak berbuat Apa-apa atau & 22,92 & 10,42 & Turun \\
& ngobrol sendiri & & & Turun \\
\hline
\end{tabular}

Berdasarkan analisis data pada Siklus I dan Siklus II sebagai penerapan pelaksanaan metode Modelling The Way dalam upaya peningkatan prestasi belajar matematika siswa dapat disajikan dalam Tabel 3.

Tabel 3. Rekapitulasi Prestasi Belajar Matematika Siswa

\begin{tabular}{llcccc}
\hline No. & Keterangan & Pretest & \multicolumn{2}{c}{ Siklus } & Keterangan \\
\cline { 3 - 4 } & & & I & II & \\
1 & Nilai Tertinggi & 80 & 100 & 100 & Meningkat \\
2 & Nilai Terendah & 20 & 50 & 60 & Meningkat \\
3 & Rata-rata Kelas & 55,45 & 71,04 & 79,17 & Meningkat \\
4 & $\%$ Ketuntasan & 41,67 & 70,83 & 87,5 & Meningkat \\
5 & $\%$ Ketidak tuntasan & 58,33 & 38,44 & 12,5 & Menurun \\
\hline
\end{tabular}

Berdasarkan hasil analisis pada Siklus I dan Siklus II sebagai penerapan pelaksanaan metode Modelling The Way dalam upaya peningkatan aktivitas dan prestasi belajar matematika siswa, selanjutnya dilakukan pembahasan lebih mendalam, yaitu:

\section{Aktivitas Belajar}

Jika dilihat dari analisis dari hasil observasi siswa selama pembelajaran dari siklus I ke siklus II mengalami peningkatan. Pada pembelajaran di siklus I aktivitas siswa sudah cukup baik. Siswa sudah mulai aktif dalam proses pembelajaran. Siswa sudah mulai berani bertanya, berpendapat dalam diskusi, mencatat, berani mengerjakan soal di depan kelas, serta antusias memperhatikan guru menyampaikan materi sudah baik. Namun masih ada kekurangan-kekurangan yang harus diperbaiki. Siswa masih ada yang bingung penerapan metode Modelling The Way. Siswa juga masih kesulitan dalam menyampaikan hasil diskusi di depan kelas hal ini dikarenakan siswa merasa belum percaya dengan kemampuan hasil diskusi dari kelompok mereka. Selain itu masih ada juga siswa yang ngobrol sendiri sehingga kurang bertanggung jawab terhadap kelompoknya dalam menjawab pertanyaan dari kelompok lain. Pada saat pembahasan hasil diskusi baik soal latihan atau pertanyaan dari kelompok lain ada sebagian siswa yang berbuat gaduh sehingga mengganggu konsentrasi siswa yang lain. Akibatnya pemahaman siswa terhadap materi kurang maksimal.

Pada pembelajaran di siklus II aktivitas siswa sudah lebih baik karena guru selalu memberikan apresisai dan motivasi kepada siswa tentang metode pembelajaran yang digunakan sehingga siswa tidak bingung dan mulai terbiasa menggunakan metode pembelajaran Modelling The Way. Pada waktu diskusi berlangsung guru selalu mencatat siapa yang sudah berkomentar dan siapa yang belum atau hanya pasif diam saja, guru meminta siswa yang pasif tersebut harus memberikan komentar tentang hasil penyajian kelompok yang telah tampil maka dengan cara demikian siswa mulai percaya diri sehingga dapat menjadikan siswa yang pasif dapat menjadi aktif dalam diskusi. Selain itu siswa yang ngobrol sendiri mulai berkurang karena sudah mulai bisa bertanggung jawab terhadap kelompoknya. Pada saat pembahasan hasil diskusi baik soal latihan atau pertanyaan dari kelompok lain siswa yang berbuat gaduh semakin sedikit, sehingga tidak mengganggu konsentrasi siswa yang lain. Hasilnya pemahaman siswa terhadap materi dapat dikuasai dengan sempurna. Siswa mulai bisa bertanggung jawab dengan kelompoknya terutama 
dalam menjawab pertanyaan dari kelompok lain, siswa yang berbuat gaduh dan hanya ngobrol sendiri sudah berkurang, sehingga tidak mengganggu konsentrasi siswa lain.

\section{Prestasi Belajar}

Berdasarkan rekapitulasi hasil belajar matematika siswa nilai tertinggi meningkat dari sebelum tindakan (pretest) maupun sesudah tindakan (post-test) sebagai berikut: nilai tertinggi naik dari 80 menjadi 100, nilai terendah naik dari 20 menjadi 60, rata-rata kelas naik dari 55,45 menjadi 79,17, persentase ketuntasan naik dari 41,67\% menjadi 87,5\%, dan persentase ketidaktuntasan turun dari $58,33 \%$ menjadi $12,5 \%$.

\section{PENUTUP}

Berdasarkan hasil penelitian dan pembahasan yang telah disajikan, maka dapat ditarik kesimpulan bahwa melalui penerapan metode Modelling The Way dapat meningkatkan aktivitas dan prestasi belajar siswa kelas IX SMP Tahun Pelajaran 2012/2013.

Beberapa saran yang dapat disampaikan berdasarkan hasil penelitian yang telah dilakukan adalah sebagai berikut: (1) bagi Guru: Dapat menciptakan suasana yang akrab dan menyenangkan. Agar dalam proses pembelajaran tidak terasa membosankan dan siswa akan menjadi lebih aktif, Dalam pemilihan kelompok hendaknya benar-benar merata agar tidak terjadi kesenjangan baik dalam kelompok maupun antar kelompok, Lebih memotivasi siswa agar berani bertanya dan mengemukakan pendapat atau hasil diskusi di depan kelas dan memberikan bimbingan bagi siswa yang kurang aktif atau mengalami kesulitan. (2) bagi siswa: fokus, serius, dan memperhatikan penjelasan guru ketika mengikuti pembelajaran dengan metode Modelling The Way, sehingga tidak bingung pada saat berlangsungnya proses pembelajaran, Lebih giat belajar di rumah untuk mempelajari materi yang akan dijadikan bahan diskusi sehingga akan lebih mudah memahami materi yang disampaikan guru walaupun hanya dengan waktu yang singkat dan akan lebih mudah berdiskusi dengan teman kelompok, Lebih meningkatkan rasa percaya diri khususnya untuk bertanya, mengemukakan pendapat saat melakukan demontrasi, ataupun mengerjakan soal di depan kelas, Membiasakan diri untuk bekerja kelompok pada saat pembelajaran berlangsung, tidak hanya bergantung pada temannya saja, karena dalam metode Modelling The Way dituntut untuk bekerja kelompok.

\section{DAFTAR PUSTAKA}

Arikunto; Suharsimi; Suhardjono dan Supardi. 2008. Penelitian Tindakan Kelas. Jakarta: Bina Aksara.

Arsaythamby, V dan Zubainur, C.M. 2015. How a realistic mathematics educational approach affect students' activities in primary schools. Procedia - Social and Behavioral Sciences. 159: 309-313.

Masoum, E., Rostamy, M., dan Kalantarnia, Z. 2013. A study on the role of drama in learning mathematics. Internatonal Scientific Publications and Consulting Services. 13: 1-7.

Susanto, H.A dan Murwaningsih,U. 2015. Improving students' activity in mathematics communication trough metacognitive learning approach based on lesson study. International Journal of Education and Research, 3 (2): 169-180.

Sutama, H dan Narimo, S. 2013. Contextual math learning based on lesson study canincrease study communication. International Journal of Education. 5 (4): 48-60.

Silberman, Mel. 1996. Active Learning. Yogyakarta: Pustaka Insan Madani.

Turgut, M dan Y1lmaz, S. 2012. Relationships among preservice primary mathematics teachers' gender, academic success and spatial ability. International Journal of Instruction. 5 (2): 5-20. 